\title{
The negation of cualquier NP
}

\author{
Ana Clara Polakof \\ UdelaR/SNI \\ anaclarapo@gmail.com
}

Received: 22-02-2021

Accepted: 29-06-2021

Published: 05-07-2021

How to cite Polakof, Ana Clara. 2021. The negation of cualquier NP. Isogloss. Open Journal of Romance Linguistics 7, 8:1-24

\begin{abstract}
Even though the interpretation of Free Choice Items such as any has been on debate for more than 50 years (Vendler, 1974, Dayal, 1998, Horn, 2000, etc.), it is relatively more recent in Spanish (Menéndez-Benito, 2005, Giannakidou and Quer, 2013, among others). Some have analyzed it as a universal quantifier, neither taking its free choiceness into account nor contexts which seem to be problematic for the universal account (see, for instance, Etxepare and Uribe-Etxebarria, 2011).

In this article, we defend that cualquier is a universal indeterminate pronoun which involves freedom of choice (as in the original proposal by Vendler, 1974). We will take into account data (taken from https://www.corpusdelespanol.org/web-dial) which has not been properly considered. We will analyze the interaction of negation and cualquier in Rioplantese Spanish in the subject position of negative generic statements, in the object position in negative episodic statements, and in a non argumental position. We will combine an alternative semantics approach to the analysis of the FCI cualquier, inspired in Menéndez-Benito (2010) and Aloni (2019), with a syntactic approach to negation inspired in Etxepare and Uribe-Etxebarria (2011).
\end{abstract}

Keywords: free choice items; cualquier NP; negation; alternative semantics; Rioplatense Spanish 
Ana Clara Polakof

\section{Introduction}

The interpretation of Free Choice Items such as any has been on debate for more than 50 years (Vendler, 1974, Hintikka, 1980, Kadmon and Landman, 1993, Dayal, 1998, Horn, 2000, etc.). The discussion on whether the Spanish FCI cualquier is a universal, an existential, both or an indefinite is relatively more recent (Menéndez-Benito, 2005, Arregui, 2006, Giannakidou and Quer, 2013, among others). Some have analyzed it as a universal quantifier, neither taking its free choiceness into account nor contexts as 1 which seem to be problematic for the universal account (see, for instance, Bustos, 1986 and Etxepare and Uribe-Etxebarria, 2011).

1. Podés sacar cualquier auto.

Can take-out any car.

'You can take-out any car.'

In this paper, we will defend that cualquier is a universal which involves freedom of choice (as in the original proposal by Vendler, 1974). To defend this, we will take into account data (taken from https://www.corpusdelespanol.org/web-dial) which has not been properly considered. We will analyze the interaction of negation and cualquier in Rioplantese Spanish, in the subject position of negative generic statements and in the object position of negative episodic statements, as in 2 and $3:{ }^{1}$

2. No cualquier jugador puede jugar en Boca.

Not any player can play in Boca.

'Not any player can play in Boca.'

3. No nos referimos a cualquier tipo de prenda, sino aquellas exclusivas de alto nivel. We.Not us.DAT refer to any sort of cloth, but those exclusive of high level.

'We do not refer to any sort of outfit, but to those exclusive of a high level'

We will assume, following Menéndez-Benito (2005, 2010), that FCI cualquier is a universal indeterminate pronoun that may be analyzed in the Hamblin alternative semantics framework of Kratzer and Shimoyama (2002). It must involve two covert operators, that are needed to explain the behaviour of the FCI as a universal indeterminate pronoun, $\forall$ and exh (following Aloni, 2007a, 2019). With their combined proposal as a framework, and a brief analysis of the interaction of negation and universal quantifiers in Spanish, we will show that the interaction of negation and cualquier NP in Rioplantese Spanish (RpS) in argumental positions can be fully explained (both semantically and syntactically).

This article has the following structure. First, we will present the approach to FCI cualquier. Second, we will present some issues related to the interaction of negation and universal quantifiers in Spanish. Third, we will present our data, and analyse it according to whether they appear as the subject of negative generic statements, or as the object of a negative episodic statement in RpS. Fourth, we will present some final considerations.

\footnotetext{
${ }^{1}$ We work with Rioplatense Spanish because it is our Spanish variety, and only Rio de la Plata examples were selected from corpus Davies at https://www.corpusdelespanol.org/web-dial.
} 


\section{Universal Free Choice Item cualquier}

Menéndez-Benito $(2005,2010)$ assumes that FC cualquier may be analyzed as an indeterminate universal pronoun which involves two covert operators, excl and $[\forall]{ }^{2}$ The alternative semantics framework of Kratzer and Shimoyama (2002) in which they are based assumes that indeterminate pronouns, as in 4, introduce alternatives which may be represented (following Aloni, 2019), as 5:3

4. Alguien/cualquiera/nadie/quién camina. 'Somebody/Anybody/N-body/Who walks.'

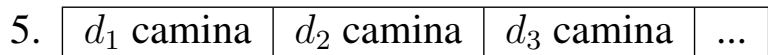

The presence of those pronouns is associated at Logical Form to operators that are taken to operate at the propositional level, by closing off the alternatives raised by the pronouns themselves. Those alternatives may expand as they combine via pointwise functional application with other categories in the sentence, as in 6 (Kratzer and Shimoyama, 2002, p. 6), in which A is the set of alternative propositions:

6. (a) $[\exists](\mathrm{A})=\{$ the proposition that is true in all worlds in which some proposition in $A$ is true $\}$

(b) $[\forall](A)=$ the proposition that is true in all worlds in which every proposition in $A$ is true $\}$

(c) $[\mathrm{Neg}](\mathrm{A})=\{$ the proposition that is true in all worlds in which no proposition in $A$ is true

(d) $[\mathrm{Q}](\mathrm{A})=\mathrm{A}$

If we take into account Spanish, the examples in 4 would involve the operators in $7: 4$

7. $\quad$ a. $[\exists]$ (Alguien camina)

b. $[\forall]$ (Cualquiera camina)

c. $[\mathrm{Neg}]$ (Nadie camina)

d. [Q] (Quién camina)

\footnotetext{
${ }^{2}$ In our paper, we will follow Aloni (2007a) in assuming exhaustification and not Menéndez-Benito (2010), because exhaustification is a laxer notion than exclusiveness.

${ }^{3}$ Even though we are aware of the problems related with the alternative semantics approach, as Aloni (ibid.) herself notes, it presents us with a solid approach to the problem of free choiceness. Regardless, Aloni and Van Rooij (2007), and van Rooij (2008) note that the use of a Hamblin-Semantics for indefinites is questionable, and they criticize the use of a covert universal propositional operator (see van Rooij (ibid.): 33). On this issue, we would also like to note that Giannakidou and Quer (2013): 135 criticize the lack of empirical evidence for the covert operators $\forall$ and Excl used by Menéndez-Benito (2010).

${ }^{4}$ We will only provide an informal presentation of the alternative semantics framework of Kratzer and Shimoyama (ibid.) to be able to explain the FC proposal we are using in this article.
} 
The problem with this framework is that it cannot explain the complex way in which FC cualquier works. It cannot explain why 8 is ungrammatical: ${ }^{5}$

8. \#Cualquiera caminó.

'Anybody walked.'

(a) $[\forall]$ (cualquiera caminó)

(b) \begin{tabular}{|l|l|l|l|}
\hline$d_{1}$ caminó & $d_{2}$ caminó & $d_{3}$ caminó & $\ldots$ \\
\hline
\end{tabular}

(c) $[\forall]($ cualquiera caminó $)=\left(\left\{\right.\right.$ that $d_{1}$ walked, that $d_{2}$ walked, $\left.\left.\ldots\right\}\right)=\{$ that everyone walked $\}$

Further problems with using this proposal were noted by Menéndez-Benito (2005), which is why she proposed an exclusiveness operator Exc to explain the ungrammaticality of 8. Menéndez-Benito (2010, pp. 41-42) puts forward her proposal for universal FC items as cualquier with two assumptions: that they are universal indeterminate pronouns as $6 \mathrm{~b}$ and $7 \mathrm{~b}$, and that a covert exclusiveness operator (triggered by the FCI cualquier) is needed to map the propositional alternatives into a set of mutually exclusive propositions, as in 9:

9. $\operatorname{Excl}(A)=\{\lambda \mathrm{w}(\mathrm{p}(\mathrm{w}) \& \forall \mathrm{q}((\mathrm{q} \in \mathrm{A} \& \mathrm{q}(\mathrm{w})) \rightarrow(\mathrm{p} \Rightarrow \mathrm{q}))): \mathrm{p} \in \mathrm{A}\}$

The exclusiveness operator ensures than in an episodic sentence a contradiction arises if it is applied directly after $\forall$. This is due to the fact that when we apply excl we generate a set of alternative propositions which cannot all occur together, because it works as a covert operator akin to only (see Menéndez-Benito, 2005). Thus, there can only be one proposition that is true, and the application of a universal operator can only yield a contradiction, as in $10:^{6}$

10. \#Cualquiera caminó. 'Anybody walked.'

(a) $[\forall]$ (Excl(Cualquiera caminó)

(b)

\begin{tabular}{|l|l|l|l|}
\hline only $d_{1}$ walked & only $d_{2}$ walked & only $d_{3}$ walked & $\ldots$ \\
\hline
\end{tabular}

(c) $\left(\left\{\right.\right.$ that only $d_{1}$ walked, that only $d_{2}$ walked,... $\left.\}\right)=\perp$

\footnotetext{
${ }^{5}$ An interesting alternative was suggested in Lasnik (1972) and Krifka (1991). Krifka shows (p. 182) that any cannot appear in episodic (non-stative) sentences, such as *Anyone can come, and that

The reason for this is that an episodic sentence reports a specific event in the real world, and as the alternative assertions are based on all possible subproperties of person', many of these alternative assertions are bound to be false, as specific events have specific participants to which not every subproperty of person' will apply. In contrast, the quantifier everyone can be restricted to a contextually salient set of persons, and therefore can be used in episodic sentences.
}

Nonetheless, following that line of reasoning would have problems to explain why cualquier $N P$ can appear in negative episodic sentences, as we will see.

${ }^{6}$ As a reviewer points out, there is no reference to tense in our paper. All of our formulas disregard tense, as is common practice in the discussion of FCI. 
Aloni (2007a, 2019) assume a more general operation than exclusiveness which is exhaustification (exh). ${ }^{7}$ Even though it is similar to exc, it is "a much more general and independently motivated notion" (Aloni, 2007a, p. 4). Exh, contrary to excl, may also apply within the boundaries of the DP. It involves an operation that takes an expression $\alpha$ of type e, which provides the domain $\mathrm{A}$, a predicate which provides the property $\mathrm{P}$, and returns an expression $\operatorname{exh}[\alpha, \mathbf{P}]$, of type $\langle\mathrm{e},\langle\mathrm{s}, \mathrm{t}\rangle\rangle$, as in 11 where $[[\alpha]]_{w, g}=\mathrm{A}$, and $[[\mathrm{P}]]_{w, g}=\{\mathrm{P}\}$, Aloni (ibid.):

\section{1. $[\operatorname{exh}[\alpha, \mathrm{P}]]]_{w, g}=\{\lambda x \lambda v \cdot x \in A \& P(x)(v) \& \forall y \in A: P(y)(v) \Rightarrow P(x) \subseteq P(y)\}$}

Since the proposal made by Aloni (ibid.) arises to explain the similarity in meaning and the different behaviour of free relatives and wh-interrogatives, two type shifts are needed in addition to exh. SHIFT ${ }_{e}$ is an entity denoting type shift, and $\mathrm{SHIFT}_{\langle s, t\rangle}$ is a propositional one. According to Aloni (ibid.), they may be analyzed as 12 and 13: ${ }^{8}$

12. Free relative: Peter read $[D P$ what Ana wrote $]$

(a) what Ana wrote type: $\langle\mathrm{e},\langle\mathrm{s}, \mathrm{t}\rangle\rangle$

(b) $\left[{ }_{D P}\right.$ what Ana wrote]: $\mathrm{SHIFT}_{e}(\operatorname{exh}[$ what, $\lambda \mathrm{x}$. Ana wrote $\mathrm{x}])$ type: $\mathrm{e}$

(c) $\left\{\right.$ the maximal collection of things that Ana wrote in $\left.\mathrm{w}_{0}\right\}$

13. Wh-interrogative: Peter knows $\left[{ }_{Q}\right.$ what Ana wrote $]$

(a) what Ana wrote type: $\langle\mathrm{e},\langle\mathrm{s}, \mathrm{t}\rangle\rangle$

(b) $\left[{ }_{Q}\right.$ what Ana wrote]: $\operatorname{SHIFTT}_{\langle s, t\rangle}(\operatorname{exh}[$ what, $\lambda \mathrm{x}$. Ana wrote $\mathrm{x}])$ type: $\langle s, t\rangle$

(c) $\left\{\right.$ Ana wrote nothing, Ana wrote only $d_{1}$, Ana wrote only $d_{2}$, Ana wrote only $\left.\mathrm{d}_{1} \& \mathrm{~d}_{2}, \ldots\right\}$

In both cases, it is the same property which type shifts into a DP denotation in 12 and into a proposition denotation in 13. ${ }^{9}$ Aloni (2007a) proposes that Italian wh-based FC items also trigger the application of $\mathbf{e x h}$, and are associated with a universal propositional quantifier $[\forall]$, which applies to the alternatives generated by exh, as in 14 (Aloni, 2019):

\section{Wh-based FC item: $[\forall] \ldots \operatorname{exh}[\mathrm{FCI}, \lambda x \psi(x)] \ldots$}

The analysis of wh-based FC items inspired on the behaviour of wh-words can be used to explain why they may appear in possibility statements alone but not in episodic statements. To be able to appear in episodic statements, they have to appear subtrigged (LeGrand, 1975). That is, they can appear in episodic statements if they are modified by a relative clause, as in 17. The idea, put forward by Aloni (2007a), is that, in much the same way as exh could apply at the IP level and at the DP level for wh-words, it can do so with wh-based FC items. When the FCI is unsubtrigged (unmodified by a relative clause), it must apply at the IP and it $\mathrm{SHIFT}_{\langle s, t\rangle}$ to generate a set of mutually exclusive propositions. That is, it behaves as a a wh-interrogative. When the FCI is subtrigged, it will apply to

\footnotetext{
${ }^{7}$ Exh is used to derive free choice effects also by Fox (2007) and Chierchia (2013), among others.

${ }^{8}$ Aloni $(2007 \mathrm{a}, 2019)$ assume that both free relatives and wh-interrogatives are born with the same predicative meaning, but have two different type-shifts.

${ }^{9}$ Aloni (2007a) follows the notion by Zeevat (1994) of exhaustive values which are normally maximal plural entities, as in $12 \mathrm{c}$.
} 
the DP level, it will SHIFT $e$ and $\downarrow$ will be applied to generate sets of individuals. That is, it behaves as a free relative, and may appear in episodic contexts. The analysis proposed by Aloni (2007a) predicts the ungrammaticality of FCI cualquier in episodic sentences, as 15 , but it also predicts their grammaticality in modal sentences, as 16 , and subtrigged cases, as $17 .{ }^{10}$

15. \#Cualquiera caminó.

'Anybody walked.'

(a) $[\forall]\left(\left(\right.\right.$ SHIFT $_{\langle s, t\rangle}($ exh[anybody, walked] $\left.)\right)$

(b) \begin{tabular}{|l|l|l|l|}
\hline nobody walked & only $d_{1}$ walked & only $d_{2}$ walked & $\ldots$ \\
\hline
\end{tabular}

16. Cualquiera puede caminar.

'Anybody can walk'

(a) $[\forall]\left(\diamond\left(\mathrm{SHIFT}_{\langle s, t\rangle}(\operatorname{exh}[\right.\right.$ anybody, walk] $))$

(b)

\begin{tabular}{|l|l|l|l|}
\hline$\diamond$ nobody walked & $\diamond$ only $d_{1}$ walked & $\diamond$ only $d_{2}$ walked & $\ldots$ \\
\hline
\end{tabular}

17. Cualquiera que intentara caminar caminó.

'Anybody who tried to walk walked'

(a) $[\forall]\left(\downarrow\left(\operatorname{SHIFT}_{e}\right.\right.$ (exh[anyone, who tried to walk]) walked)

(b) $d_{1}$ walked $d_{2}$ walked

In 15 and 16, exhaustification undergoes $\operatorname{SHIFT}_{\langle s, t\rangle}$ which explains the partitions we get in both cases. In 15, the partition results in a contradiction, as it did in 10c. In 16, we first generate a set of exclusive propositions. Then, the modal operator expands the possibilities. Finally, we apply the universal propositional quantifier. Since it is quantifying over possibilities, no contradiction arises. ${ }^{11} \mathrm{Up}$ to now, this proposal can predict almost the same results as Menéndez-Benito (2005). The difference resides in 17 in which, according to Aloni (2007a), exhaustification occurs within the DP, which is why it undergoes SHIFT $_{e}$. It yields as an output the sum of all the people that tried to walk in $w$. $\downarrow$ is applied to avoid trivial quantification, and produces a set of singular individuals. In addition to this, Aloni (2019) argues that the necessary association of FCI with exh and $\forall$ may be found diachronically. According to her (p. 7), exh comes plausibly from wh-morphology, while $\forall$ comes from earlier universal-uses of the wh-based forms.

Aloni (2007a, 2019), and Menéndez-Benito (2010) provide an approach to FC cualquier that may deal with episodic and modal statements. Nonetheless, they have not dealt with the interaction of negation and cualquier. To deal with it, an analysis of the interaction of negation and universal quantification needs to be provided. In the next section, we will present some theoretical approaches to the interaction of negation and universal quantification in Spanish which we will use as a framework for the analysis of the interaction of negation and FC culaquier in Rioplatense Spanish.

\footnotetext{
${ }^{10}$ For an analysis of how the subjunctive interacts with the FC cualquier, see Rivero (2011).

${ }^{11}$ The order has to be the one in 16 , because if it were not, contradictions would arise.
} 


\section{Negation and $\forall$ in Spanish}

Beghelli and Stowell (1997) noted that the interaction of negation and universals is complex. Phrases headed by each behave differently from those headed by every, and they behave differently from the definite universal all. ${ }^{12}$ In regular neutral sentences, the cooccurrence of negation and a universal quantifier results in negation taking scope over the universal (Beghelli and Stowell, 1997, Ricardo Etxepare and Myriam Uribe-Etxebarria, 2008, Zeijlstra, 2004, among others). However, negated quantifier phrases behave differently in the subject and in the object position (Beghelli and Stowell, 1997, Collins and Postal, 2014, Collins, 2017, among others).

Bosque (1980) was one of the first comprehensive studies of Spanish negation, though probably some of the issues dealt with there were popularized by Laka (1990). As is wellknown by now, Spanish is a Romance language which has pre-verbal negative markers, as in 18, and a negative concord language (Zanuttini, 1997, Laka, 1990, Corblin and Tovena, 2003 among others), as in $19 .{ }^{13}$ In addition to this, negation does not scope over non-negative existential quantifiers such as alguna in 20 (in Sánchez López (1999a, p. 2581)), while it does scope over universal quantifiers, as in 21 (in Sánchez López (ibid., p. 2583): ${ }^{14}$

18. Juan no trabaja aqui.

Juan not works here.

'Juan does not work here.'

19. No vino nadie.

not came anybody

'Nobody came.'

20. El presidente no respondió alguna pregunta.

The president did not respond some question.

'There is a question that the president did not answer.'

21. Todos los libros de Cela no me gustan.

All the books of Cela I do not like.

'I do not like all of Celas books.'

Ricardo Etxepare and Myriam Uribe-Etxebarria (2018) note that there are two possible configurations for the interaction of negation and Quantifier Phrases (QP) in the subject position in Spanish. The first one, exemplified in 22 (ibid., p. 78), gives rise to sentential negation, and the QP appears distanced from negation, which is why they are incompatible with positive polarity items (PPI), such as al menos 3 articulos/at least 3 articles. The second one, exemplified in 23 (ibid., p. 78), gives rise to constituent negation, and the QP appears directly negated, which is why they are good with PPI.

22. *Muchos lingüistas no han publicado al menos 3 artículo.

\footnotetext{
${ }^{12}$ This is something that Vendler (1974) had already noted, as is well-known.

${ }^{13}$ Whether n-words in Spanish are polarity items, and whether they have to be interpreted as $\exists$ or $\forall$ is not a discussion into which we will enter. It has been broadly discussed in Bosque (1980), Laka (1990), Zanuttini (1997), Espinal (2000), among many others.

${ }^{14}$ An existential quantifier may only be under the scope of negation if it assumes the form of an n-word as in 19 .
} 
many linguists neg have published at least 3 articles.

* 'Many linguists haven't published at least 3 papers.'

23. No muchos lingüistas han publicado al menos 3 artículos

neg many linguists have published at least 3 papers

'Not many linguists have published at least 3 papers.'

Ricardo Etxepare and Myriam Uribe-Etxebarria (2018) argue, however, that even though many quantifiers can appear in NEG+QP, the analysis of constituent negation cannot be extended to all cases (pace Sánchez López, 1999a and Kim and Sag, 2002). The universal quantifier todos may appear in a NEG+QP sequence, but accepts negative polarity contexts which are not allowed by quantifiers as pocos, in 24 (from Etxepare and Uribe-Etxebarria, 2011, p. 236).

24. a. Han venido no todos los dirigentes ni simpatizantes, sino solo algunos.

Have come not all the directives nor simpatizers, buy just some.

'Not all the directives no simpatiers have come, only some."

b. *Han venido no pocos dirigentes ni simpatizantes.

*Have come not little directives nor simpatizers.

'*Not little directives nor simpatizers have come.

Etxepare and Uribe-Etxebarria (ibid.) argue that 24a shows that, even though there is a NEG $+\forall$ sequence, negation is external. Thus, it is not constituent negation. In addition to this, in p. 236, they show that the interaction of NEG+QP with prepositions or case markers is also different. Whereas the preposition must precede NEG+pocos NP, it cannot precede NEG+todos (which basically coincides with how English works, see Collins, 2017), as in 25 and 26 (from Etxepare and Uribe-Etxebarria, 2011, p. 236). Since the preposition cannot appear in a higher position, negation has scope over the universal quantifier. $^{15}$

25. a. A no pocos les gusta el vino.

To not few them.DAT like the wine.

b. *No a pocos les gusta el vino.

* Not to few them.DAT like the wine.

26. a. *A no todos les gusta el vino.

*To not all them.DAT like the wine.

b. No a todos les gusta el vino

Not to all them.DAT like the wine.

The possibility of negation appearing in coordinated sentences which involve two universal quantifiers is, according to them (236-237), further evidence of the external character of the negation that interacts with universal quantifiers, in 27:

27. No [IP a todo el mundo le gusta el vino] o [IP a cualquiera $\phi$ el café].

\footnotetext{
${ }^{15}$ Even though this should be the behaviour, they do note in Ricardo Etxepare and Myriam UribeEtxebarria (2018) that a corpus analysis shows that the sequence preposition $+\mathrm{NEG}+\forall$ does exist. They provide an explanation of the phenomena by a scalar analysis. Nonetheless, since we are not trying to provide an analysis of negation, we will not enter into these problems.
} 
Not ${ }_{I P}$ to all the world is the wine liked] or [ ${ }_{I P}$ to anybody $\phi$ the coffee $]$

A further corroboration of the external character of the negation of todo is reflected by the fact that it does not allow for sentential ellipsis. Etxepare and Uribe-Etxebarria (2011) defend that, since it cannot operate sentential ellipsis, the quantifier todos occupies an internal position of IP, and does not survive ellision, as in 28 , and should have the structure in 29:

28. Ha ido donde no todos *(han ido).

'(She) has gone where not all *(have gone).'

29. $\left[{ }_{\text {NegP }} \text { No }\left[{ }_{I P} \ldots \text { todos... }\right]\right]^{16}$

Summing up, they defend that NEG $+\forall$ does not correspond to a syntactic constituent. It is thus sentential negation. Their approach will allow us to see whether the behaviour of FC cualquier patterns with a universal or not. If we can show that its interaction with negation has as a result sentential negation, regardless of the position the negative marker has with regards to it in an argumental position, then it must be analyzed as a universal.

In the next section, we will present a description of the negation of cualquier, and the analysis of the data we obtained at corpus Davies.

\section{The negation of cualquier}

There have been, as mentioned, some descriptions of the interaction of negation and cualquier. It has been dealt with as the negation of a universal quantifier, though its free choiceness has not been taken into account. Bustos (1986), RAE (2009), among others, argue that negation has scope over cualquier. Since the scope is independent on whether cualquier precedes or not no, it has been argued that it is a universal (Bustos, 1986), as may be seen in the following examples in which, according to RAE (2009), the scope relation is maintained:

30. No cualquiera es capaz de guardar silencio.

'Not anyone is capable of keeping silence.'

31. Cualquiera no puede ser ladrón solo con quererlo.

'Anyone not can be a thief just by wanting it.'

\footnotetext{
${ }^{16}$ Even though this sentential negation may sometimes be called external negation, it is not the same as the external metalinguistic negation. In Spanish, the external metalinguistic negation involves the projection of a higher negation phrase that is used to object to a previous assertion which may be implicit or explicit, and may be combined with our sentential negation (Neg2), as in a (a simplified version of the example provided by Ricardo Etxepare and Myriam Uribe-Etxebarria, 2018, p. 95) which can be represented syntactically as b, as (ibid., p. 96) propose:

(a) ... no todos no quieren trabajar en el campo.

...neg all neg want work.inf in the land. ... not all of them do not want to work in the land.

(b) $\left[{ }_{N e g P 1} \mathrm{No}_{N e g 1}\left[\ldots\left[N e g P 2 \mathrm{No}_{N e g 2}\left[{ }_{I P}\right]\right]\right]\right]$

We will argue that the negation that interacts with cualquier is not the metalinguistic negation (see also Ricardo Etxepare and Myriam Uribe-Etxebarria (2020)).
} 
Ricardo Etxepare and Myriam Uribe-Etxebarria (2018) assume, following Sánchez López (1999b), that cualquier sometimes has an existential value, and sometimes a universal. Thus, they explain the differences between 32 and 33 by assuming that $32 \mathrm{~b}$ is ungrammatical because 32a does not have the universal reading available, while 33 a does have it. ${ }^{17}$ They argue that in 32 , it is not just the existential value which renders $32 \mathrm{~b}$ ungrammatical. According to them, de estos introduces a non-scalar reading of days that forces them to be interpreted as similar. ${ }^{18}$

32. (a) Cualquier día de estos me suicido any day of these CL.reflex commit.suicide(I)

'One of these days I just might kill myself.'

(b) *No cualquier día de estos me suicido. neg any day of these CL.reflex commit.suicide(I) 'I won't kill myself one of these days.'

33. (a) Cualquier día es bueno para suicidarse. any day is good for committing suicide 'Any day is a good one to commit suicide.'

(b) No cualquier día es bueno para suicidarse. not any day is good to commit suicide 'Not just any day is a good one to commit suicide.'

The ungrammaticality of $32 \mathrm{~b}$ is not easy to explain for a universal approach to cualquier, and it should be explained if we want to have a unified approach to the behaviour of the FCI. It is a case of a local or constituent negation, because the negative phrase functions as an adjunct and is not an argument of the sentence (Kato, 2000). Thus, the negation of cualquier día de estos does not negate the possible event of suicide, but negates an implicit temporal predicate which involves the location of the event in any of these days (see Penka, 2016). ${ }^{19}$ Since we are not dealing with constituent negation nor are we dealing with non-argumental positions in this paper, we will leave this problem unresolved for now. ${ }^{20}$

\footnotetext{
${ }^{17}$ The examples and the glosses are taken from Ricardo Etxepare and Myriam Uribe-Etxebarria (2018).

${ }^{18}$ They defend a scalar approach to explain different interactions of negation, quantifiers and prepositions.

${ }^{19}$ Since constituent negation can be paraphrased by a relative clause, it could be argued that the whole sentence could be paraphrased as En un tiempo que no está localizado en cualquier día de estos, me suicido/In a time that is not located in any day of theses, I will kill myslef which would make the implicit temporal predicate explicit (see ibid.).

${ }^{20}$ We do think that it should involve the negation of a universal quantifier over instants of time, and that the PP de estos which introduces an indexical (Kaplan, 1989) may be responsible both for the grammaticality of $32 \mathrm{a}$ and the ungrammaticality of $32 \mathrm{~b}$. Note that, without the PP, the sentence is not good even without negation, at least in Rioplatense Spanish, as in (in which we have glossed cualquier as any):

1. \# Cualquier día me suicido any day CL.reflex commit.suicide(I) \# 'Any day I kill myself.'

2. \# No cualquier día me suicido. neg any day of these CL.reflex commit.suicide(I) 'Not just any day I kill myself.'
}

Two of the reviewers noted that they find that example 1 of this footnote sounds good for them. This is not the case in Rioplatense Spanish in which examples as 1 and 2 do not sound good. 
In the following sections, we will present data from Rioplatense Spanish taken from https://www.corpusdelespanol.org/web-dial/ which shows, first, how negation and FCI cualquier interact in the subject position in generic statements, and, second, how they interact in the object position in negative episodic statements. We will analyze the interaction of negation and cualquier in generic statements because, as far as we know, the Spanish literature has not dealt with them, and they are registered in our corpus. We will analyze negative episodic statements, because they have been used to argue in favour of a metalinguistic negation and an existential value of FC items (see Arregui, 2006, Horn and Katō, 2000. Horn, 1985, Chierchia, 2006, among others) and have been problematic for those that defend that FCI have universal value (see Dayal, 1998 and Dayal, 2009). We will show that the interaction is better explained if we assume that cualquier involves universal quantification.

\subsection{Negated cualquier NP in the subject position in generic statements in $R p S$}

The negation of cualquier NP in the subject position may occur both preceding it and succeeding it. In the subject position, the negated cualquier NP appears in non-episodic, negated universal sentences. ${ }^{21}$ Their affirmative counterparts are completely grammatical, and their negation involves its polar counterpart ((Löbner, 2000). They are not problematic for an account as ours, because the negated meaning is derived by the application of negation to a universal proposition. ${ }^{22}$

We will analyze, first, those sentences which involve a modal verb. Second, we will analyze those sentences which only involve universal/generic meaning. This is due to the fact that the proposal we presented in 2 can explain modal behaviours, but it does not seem to be appropriate to explain generic behaviour alone.

34. No cualquier jugador puede jugar en Boca.

'Not any player can play in Boca.'

35. No cualquier periodista puede ser enviado a zonas de guerra.

'Not any journalist can be sent to war zones'

36. Cualquier estrella no puede pelear

Any star not can fight.

'Any star cannot fight.'

37. Cualquier persona no puede interpretar [el Corán]

Any person not can interpret [the Koran].

'Any person cannot interpret the Koran.'

\footnotetext{
${ }^{21}$ There are examples in the corpus in which the negated cualquier appears in other syntactic positions in generic statements, as in 1 .

1. Un hijo no es cualquier cosa.

'A son is not any thing.'

We will not analyze those kind of examples. Nonetheless, our proposal may be extended to cualquier NP in different argumental positions in negated universal sentences, because negation scopes over the universal as well.

${ }^{22}$ They are problematic for those that defend that it will yield an existential reading, unless they recur to metalinguistic negation as Arregui (2006). Nonetheless, the metalinguistic explanation does not explain the polar meaning it has.
} 
These examples show the expected behaviour of a universal quantifier, and disallow an existential interpretation. Since these examples show that negation scopes over cualquier regardless of its position, it can only be the negation of a universal. We can explain this behavior if we use the alternative semantics framework we presented, as well as the data with regards to the interaction of negation and the universal quantifier in Spanish. NEG has scope over $\forall$. Thus, they can be represented as 38-39, where the modal operator expands the possibilities and avoids a contradiction, as it did in 16:

38. No cualquier jugador puede jugar en Boca. $[\mathrm{NEG}][\forall]\left(\diamond\left(\mathrm{SHIFT}_{\langle s, t\rangle}(\right.\right.$ exh[any player, play in Boca] $\left.)\right)$

39. Cualquier estrella no puede pelear $[\mathrm{NEG}][\forall]\left(\diamond\left(\mathrm{SHIFT}_{\langle s, t\rangle}(\right.\right.$ exh[any star, fight $\left.\left.]\right)\right)$

The problem with the framework we presented in 2 is that, even though it may explain cases as the previous ones, it cannot explain perfectly grammatical sentences which involve generic meaning, but do not involve any modal verb, as the examples below. It would predict that they should be ungrammatical, as it did for 14. Thus, a modification is needed to explain the grammaticality of 40-44:

40. Cualquier cosa no es arte pero si [sic] contemporáneo.

Any thing not is art but yes contemporary.

'Any thing is not art, but is contemporary.'

41. Cualquier verdad no es buena en sí misma.

Any truth not is good in itself.

'Any truth is not good in itself.'

42. Esto significa que no todo o cualquier afección, material o moral, se encuentra amparada por el derecho.

This means that not all or any affection, material or moral, $\mathrm{PASS}_{s e}$ finds protected in law.

'This means that not all or any affection, material or moral, is protected by the law.'

43. No cualquier hecho es noticia.

'Not any fact is news'.

44. No cualquier persona hace eso.

'Not any person does that.'

One solution would be to propose that they involve an omitted possibility modal, and could be analyzed as the other examples. Nonetheless, they do not express the same when the modal verb is present, as may be seen in 45 . Thus, there is no omitted possibility modal and another explanation needs to be found.

45. No cualquier persona hace eso. $\neq$ No cualquier persona puede hacer eso, 'Not any person does that.' $\neq$ 'Not any person may do that.'

Another option would be to follow Menéndez-Benito (2010), and analyze them as generic sentences. However, we agree with Dayal (1998) in that genericity is not the same as universality. In this case we have the FCI cualquier which is a universal indeterminate pronoun that gives the proposition a general flavour. 
The option we will follow is to propose a modification in Aloni (2007a, 2019) which involves the possibility of slightly changing 14 , repeated here as 46 , to account for the generic flavour as well as the acceptability of the examples from 40 to 44 .

46. (a) \#Cualquiera caminó.

'Anybody walked.'

(b) $[\forall]\left(\left(\right.\right.$ SHIFT $_{\langle s, t\rangle}($ exh[anybody, walked] $\left.)\right)$

(c) \begin{tabular}{|l|l|l|l|}
\hline nobody walked & only $d_{1}$ walked & only $d_{2}$ walked & $\ldots$ \\
\hline
\end{tabular}

As Aloni (2007a) and Menéndez-Benito (2010) argue, 46 is out because it involves a contradiction: all of those propositions cannot be true in that context. However, negated generic sentences do accept cualquier $N P$, and some explanation must be found. We will base our modification in Dayal (1998), where a combination of $\forall$ and GEN is used to explain the generic meaning of sentences such as $47:^{23}$

47. (a) Any lion is majestic.

(b) $\forall \mathrm{s}$, $\mathrm{x}[\operatorname{lion}(\mathrm{x}, \mathrm{s}) \& \mathrm{C}(\mathrm{s})]$

[GEN s' [s < s' \& C'(s')] [majestic(x, s')]] (Dayal, 1998: 449)

We will propose that, once we have the partition of the logical space provided by the application of $\mathrm{SHIFT}_{\langle s, t\rangle}$ to exh, the generic operator applies to the set of propositional alternatives generated by $\mathbf{E x h}$ and provides us with a generic interpretation similar to the one found with indefinite generics. ${ }^{24}$ GEN is a modal, and does not commit ourselves with the actual existence of a singular proposition (see Chierchia, 1998: 381). The idea is that, in a sentence like 48a, there are two sources of genericity, one that is indicated by the verbal aspect, which triggers GEN, and another with the FCI cualquier, which triggers $\forall$, as in p. 447 in Dayal (1998). Thus, the universal quantifier is quantifying over possible propositions, which are generated by the application of GEN to the alternatives in 48c, and no contradiction arises. Finally, negation may be applied to get a meaning which is $\neg \forall$. Then, a sentence as 41 , repeated here as 48 , is represented in $48 \mathrm{~b}$ :

48. (a) Cualquier verdad no es buena en sí misma.

(b) $[\mathrm{NEG}][\forall]$ GEN $\left(\left(\mathrm{SHIFT}_{\langle s, t\rangle}(\operatorname{exh}[\right.\right.$ any truth, good on its own] $))$

(c) \begin{tabular}{|l|l|l|l|}
\hline no truth is good & only truth $_{1}$ is good & only truth $_{2}$ is good & $\ldots$ \\
\hline
\end{tabular}

If this modification is introduced, it allows us to explain the availability of the universal sentences above which have a sort of generic flavour, but involve nonetheless universal quantification. ${ }^{25}$ Thus, it is not just the application of GEN, which is modal in nature and

\footnotetext{
${ }^{23}$ Our proposal is also similar to that of Menéndez-Benito (2010) for generic necessity sentences such as Cualquier auto debe tener cinturón/Any car must have seatbelts. However, her proposal subsumes the universality into GEN, and as Dayal (1998) and Krifka et al. (1995) note, they are not strictly the same.

${ }^{24}$ This could explain the similarities found between generics involving FCI as originally proposed by Kadmon and Landman (1993), and also noted in the case of generic necessity statements in Spanish by Menéndez-Benito (2005) and Menéndez-Benito (2010).

${ }^{25}$ Clear examples of generic sentences with a universal quantifier involve todo NP, as in Todo hombre es mortal/All men are mortal, Todo pájaro vuela/All birds fly, etc.
} 
a part of the verbal aspect (Krifka et al., 1995, Chierchia, 1998, among others). The need for the universal quantifier is made clear in example 42 in which we have a coordination of todo and cualquier mediating negation. We think that the addition of GEN in these contexts, while also having $\forall$, allows us to explain the behaviour of cualquier NP in negative generic sentences, but it could also explain why other generic sentences (such as the necessity generic sentences analyzed in Menéndez-Benito, 2010) allow the use of cualquier NP. ${ }^{26}$ With these analysis at hand, we should rewrite the examples 34-37 to include the GENERIC operator, since they are generic statements as well: ${ }^{27}$

49. No cualquier jugador puede jugar en Boca.

$[\mathrm{NEG}][\forall] \mathrm{GEN}\left(\diamond \mathrm{SHIFT}_{\langle s, t\rangle}(\operatorname{exh}[\right.$ any player, play in Boca $\left.])\right)$

Before concluding this section, we want to say something about the difference in the syntactic structure of the sentences which do appear to have constituent negation (34-35 and 42-44) from those that do not (36-37 and 40-41). We will argue, following Etxepare and Uribe-Etxebarria (2011), that both are cases of sentential negation in which the negative operator is semantically associated with the focus of the sentences, without it implying a direct merge. In the first cases they will have the structure 29 , rewritten here as 50 with the presence of cualquier $N P$, and in the second cases they will involve a movement to a FocusP which "is the one available in ordinary negative sentences in Spanish" (Ricardo Etxepare and Myriam Uribe-Etxebarria, 2018, p. 97), as in 51:28

50. $\left[{ }_{\text {NegP }}\right.$ No $\left[{ }_{I P} \ldots\right.$ cualquier NP...]]

51. [FocP CUALQUIER NP Foc ${ }^{o}\left[\mathrm{NegP}_{2} \mathrm{No}_{\mathrm{Neg} 2}\left[{ }_{I P} \ldots\right.\right.$ (cualquier NP) $\left.\left.]\right]\right]$

We conclude, then, that even though in one of the group of sentences there is a FocP, the semantic representations involve the same kind of polar interpretations, and thus do not differ.

In the next section, we analyze the negated cualquier $N P$ in the object position of negative episodic statements.

\subsection{Negated cualquier NP in the object position in episodic statements in $R p S$}

The negation of cualquier NP in the object position has been analyzed as a metalinguistic negation of an indefinite (Arregui, 2006, Chierchia, 2006, Horn and Katō, 2000, among

\footnotetext{
${ }^{26}$ Note that the proposal of Menéndez-Benito (ibid.) is inspired by Aloni (2007b) which explains the apparition of any in modal generic statements with the use of GEN. However, in that paper, an existential account is provided and she proposes that GEN has scope over the existential and must so that the universal interpretation is available, in page 84. Since we are dealing with $\forall$, it can scope over GEN.

${ }^{27}$ As a reviewer noted, my analysis of 49 may lead us to think that FCI are out when we are in front of strictly modal statements. However, 49 is not intended to negate that FCI can appear in modal statements, such as:

1. No cualquier jugador pudo jugar en Boca. Not any player could play in Boca.

In fact, 16 can be used to explain why it can appear in such modal statements.

${ }^{28}$ As a reviewer points out 51 involves a focus position, which is closer to topicalization. We are not arguing that it cannot appear in heavily focalised statements, but the examples provided by the corpus do seem to favour the analysis proposed by Ricardo Etxepare and Myriam Uribe-Etxebarria (ibid.).
} 
others). Arregui (2006) defends that cualquier can only appear within a metalinguistic negation, which should involve an objection to a previous utterance, and special intonational contour, as in:

52. (Who was that lady I saw you with last night?) That was no lady, that was my wife. (Horn, 1985: 134)

53. No compró CUALQUIER libro, compró Estructuras Sintácticas. not bought any book, bought Structures Syntactic

'He/She didn't buy (just) ANY book, he/she bought Syntactic Structures' (Arregui, 2006: 14)

Even though cualquier may be said to appear in a metalinguistic negation in the example above, we have shown that it does appear, at least in the subject position of generic statements, within the scope of ordinary negation. In the object position of negative episodic statements, it is always preceded by negation, and it does not appear to be subtrigged, as in 54-57: ${ }^{29}$

54. No nos referimos a cualquier tipo de prenda, sino aquellas exclusivas de alto nivel. We.Not us.DAT refer to any sort of cloth, but those exclusive of high level.

'We do not refer to any sort of outfit, but to those exclusive of a high level'

55. No enviaron a cualquier periodista a cubrir el viaje de el candidato, sino a sus informativistas principales.

They.Not sent to any journalist to cover the trip of the candidate, but to their news important.

'They did not send any journalist to cover the trip of the candidate, but their main newsreporters.'

56. No agarré cualquier historia y la produje aunque no tuviera nada que ver con lo que creo.

I.not grabbed any history and it.ACC produced even.though not had n-thing that see with it.ACC that I.believe

'I did not grab any story and produced it even though it had nothing to do with what I believe'

57. No queremos cualquier verdad.

We.not want any truth.

'We do not want any truth.'

If it were metalinguistic negation, the metalinguistic negation should operate on a universal implicature that would arise from an existential value and generate the metalinguistic interpretation (Arregui, 2006). ${ }^{30}$ In addition to this, only special contexts should enable it's use. However, since we have shown that there is an interaction between negation and the universal FCI cualquier, and since there are many examples of this sort of negation which do not involve special intonational contours or do not involve the cancellation of implicatures, we are prone to think that it is not metalinguistic negation, and that

\footnotetext{
${ }^{29}$ For the difference between cualquier historia and una historia cualquiera, see Alonso-Ovalle and Menéndez-Benito (2011)

${ }^{30}$ The metalinguistic negation should operate on what is communicated and not on what is said (Grice, 1975). Thus, to get the proper meaning, the implicature should arise from an existential value to a universal value.
} 
it still is the negation of a universal. The examples provided in Arregui (2006), as 53 here, seem to involve corrections of a previous utterance, and a reference to a single defined entity as Syntactic Structures. Nonetheless, they do not exhaust the possible combinations. The sentence which involves the negation may be followed by a sentence with a plural object, which is what happens in our first two examples. Thus, it is not a correction. It involves a restriction of the domain to which the properties apply, and it may involve singular or plural entities.

The meaning we obtain in those sentences can only be explained, without recurring to implicatures, if it is the negation of a universal quantifier. The presence of a phrase headed by sino in 54 and 55 introduces a correction (Sánchez López, 1999a) which is the result of the sentential negation of a universal proposition: we have the universe of all journalists in 55 and of all kinds of clothes in 54, and we restrict its domain to some particular instances which are included in the universal domains denotation. ${ }^{31}$

The FCI may also denote a single entity, as in 56 and 57. In those cases, the agent selects or wants a particular entity and not every entity. Whether they are referring to multiple entities or a single one depends on the choice the speaker makes, respecting the freedom of choice that FCI have, and the alternatives introduced by cualquier.

We have argued that it is not metalinguistic negation. We still need to explain why cualquier NP may appear in negative episodic statements in the object position. Since

\footnotetext{
operates only on metalinguistic negation (see 3) [San Segundo Cachero (2016)]

1. Xuan nun tien tres fíos $\downarrow$, [tien dos] Regular negation Juan not has three sons, he has two.

2. Xuan nun tien tres fíos $\uparrow$, [tien cuatro] Metalinguistic negation Xuan not has three sons, he has four.

3. Xuan tien tres fíos non, [tien cuatro] Metalinguistic negation Xuan has three sons not, he has four.
}

${ }^{31}$ Further evidences for this correction operating on sentential level and not on the discursive level come from Central and Western Asturian which has two words for the negative marker no: nun and non. The first one can operate both on regular sentential negation and metalinguistc negation (see 1 and 2 ). The second

San Segundo Cachero (ibid.) argues that in Central and Western Asturian the metalinguistic negation cannot occur with the presence of the coordinating sinon/sino/but?. He argues (pp.82-83), inspired in Lorenzo González (1999), that this is due to the fact that it coordinates two constituents of the same sentence, and thus the negation can only be sentential, which is why examples 5 and 6 with the metalinguistic non are out:

4. Ta caliente non, ferviendo Metalinguistic negation

[it] is hot not, [it is] boiling

5. *Ta caliente non, sinón ferviendo

*[it] is hot not, but [it is] boiling

6. *Ta caliente non, sinón que ta ferviendo

*[it] is hot not, but that [it is] boiling

Thus, these data confirm our intuitions: it is sentential negation. Even though Spanish does not have the two items, it seems to be possible to have the same readings by reduplicating no, as in:

7. No está caliente no, está hirviendo.

Not [it] is hot not, [it] is boiling.

This would be further evidence for the two NegP that Ricardo Etxepare and Myriam Uribe-Etxebarria (2018) argued for. However, this is not an issue we will solve in this paper, and will be interesting to research in the future. 
negation does not affect episodicity, a non-subtrigged statement should be out (see Dayal, 2009). Our examples show, nonetheless, that they are not out. Thus, to account for the grammaticality of the sentences here analyzed, we will use the idea, presented in Dayal (1998) and Dayal (2004), that some modifications (such as a relative clause or other phrasal modifiers) may be covert, and that some episodic sentences which accept the presence of an unmodified any may only be interpreted if we assume that there is some covert modification, as in 58 and 59:

58. Bill may read any book (he finds)/(on his reading list). (Dayal, 2009:2)

59. After the dinner, we threw away any leftovers. (Dayal, 1998: 446)

What makes 59 acceptable, according to Dayal (ibid.), is that it is possible to introduce a modification such as that we saw which introduces some sort of temporal bound to the interpretation. In the absence of an explicit modification, we would need some clues which would allow us to interpret sentences as 59. In the case of negative episodic sentences, we will propose that they involve a covert modifier which presupposes a selection, such as that I can choose. Thus, they would be subtrigged cases which would allow for a type shift e and the apparition of cualquier NP in negative episodic sentences. This would also allow us to explain why cualquier NP in negative episodic sentences only appears in the object position: there must be an agent that has the ability to choose between the alternatives introduced by the FCI. Thus, the sentences would be read as (only two examples are rewritten):

60. No enviaron a cualquier periodista (que pudieran elegir) a cubrir el viaje de el candidato, sino a sus informativistas principales.

'They did not send any journalist (that they could choose) to cover the trip of the candidate, but their main newsreporters.

61. No agarré cualquier historia (que pudiera elegir) y la produje aunque no tuviera nada que ver con lo que creo.

'I did not grab any story (that I could choose) and produced it even though it had nothing to do with what I believe'

Basically, we are saying that they can be interpreted as the cases which involve subtrigging in episodic sentences, and may be formalized as

62. (a) No agarré cualquier historia (que pudiera/quisiera elegir)...

(b) $[\mathrm{NEG}][\forall]$ (Yo agarré $\downarrow$ (SHIFT ${ }_{e}$ (exh[cualquier historia, que quisiera elegir]))

$\operatorname{SHIFT}_{e}$ (exh[cualquier historia, que quisiera elegir]) yields the maximal collection of histories I could choose in $w_{0}$. To avoid vacuous quantification, $\downarrow$ is applied and produces a set of individuals. Then, it combines with the denotation of the verb to produce the set of alternatives presented before. Since the set occurs in the scope of a negated universal operator, we get the desired interpretation: not every story was chosen by me.

The previous representation correctly predicts that the agent did not select all of the possible alternatives. She selected the ones that she wanted to select, thus the free choiceness effect is maintained even within the scope of negation. Since $\neg \forall$ is logically equiv- 
alent to $\exists \neg$ (see Gamut, 2002), we get the existential some are not reading that has lead Arregui (2006) to propose that we are dealing with metalinguistic negation. ${ }^{32}$

Finally, with regard to its syntactic representation, these sentences do not represent any problem at all, since they are strictly speaking a sentential negation which has the prototypical structure that would be represented as:

$$
\text { 63. }\left[{ }_{\text {NegP }} \text { No }\left[{ }_{I P} \ldots \text { cualquier NP...] }\right]\right.
$$

In negative episodic sentences, we are in front of a sentential negation in all of the cases which involve the negation of cualquier NP. Thus, we may conclude that we are not dealing with metalinguistic negation, but with the negation of $\forall$.

\section{A note on example 32}

Since for a unified account of the interaction of negation and cualquier we should explain example 32 , here as 64 , we will try to sketch a solution to the problem at hand. Some important issues with the example are: it involves a non-argumental negation and not sentential negation, it involves a single-event predicate, it involves an indexical, it is grammatical in a, and ungrammatical when negation is involved, as in $b:^{33}$

64. (a) Cualquier día de estos me suicido any day of these CL.reflex commit.suicide(I) 'Any day of these I just might kill myself.'

(b) *No cualquier día de estos me suicido. neg any day of these CL.reflex commit.suicide(I) 'Not just any day of these I might kill myself.'

To explain why a) is grammatical, and b) is ungrammatical, we have to take into account the fact that what makes a) grammatical is the presence of a PP which involves an indexical which allows us to refer to instances of times in the world. Most importantly, we need to analyse it as a case of subtrigging because the same constituent unsubtrigged is not good in Rioplatense Spanish, as in 65. If we replace de estos with another modifier, instead, the sentence is grammatical when non-negated and ungrammatical when negated, as in 66. Thus, subtrigging, as well as its apparition in a non-argumental position, seems to be playing a fundamental role.

65. (a) \# Cualquier día me suicido

\footnotetext{
${ }^{32}$ Note that this proposal can also explain why cualquier may be combined with modifiers such as casi/almost, as in a.

1. Casi cualquiera que llegó tarde se quedó sin entrar. (Gutiérrez-Rexach, 2014: 109) 'Almost anyone that arrived late could not enter.'

We have not included this piece of evidence in the main text, because it does not involve the interaction of negation and cualquier:

2. *No casi cualquiera que llegó tarde se quedó sin entrar. '*Not almost anyone that arrived late could not enter.'

${ }^{33}$ The examples have been re-glossed to have any as the translation of cualquier.
} 
any day CL.reflex commit.suicide(I)

\# 'Any day I kill myself.'

(b) \# No cualquier día me suicido.

neg any day of these CL.reflex commit.suicide(I)

'Not just any day I kill myself.'

66. (a) Cualquier día que quiera me suicido

any day that (I) want CL.reflex commit.suicide(I)

'Any day that I want I just might kill myself.'

(b) *No cualquier día que quiera me suicido.

neg any day that (I) want CL.reflex commit.suicide(I)

'Not just any day that I want I might kill myself.'

It could be argued that example 65 is out because it has an unbounded universal reading which is incompatible with the single-event predicate (see Carlson, 1989). ${ }^{34}$ Then, we could argue that what makes 64a grammatical is the subtrigging, which allows for a referential reading of cualquier día de estos. However, even though subtrigging could explain the grammaticality of 32a, or 64a, it does not explain the ungrammaticality of 32b, or $64 \mathrm{~b}$. The fact that we are dealing with constituent negation also seems to be playing an essential role, since in similar cases in which we are dealing with sentential negation, both statements, the affirmative and the negative, are grammatical, as in:

67. (a) Cualquier persona que quiera se suicida.

'Any person that wants to can commits suicide.'

(b) No cualquier persona que quiera se suicida.

'Not any person that wants commits suicide.'

Thus, we have to explain why subtrigged cases of non-argumental cualquier $N P$ are allowed with single-event predicates like to commit suicide while NEG cualquier NP are not, and how to sustain the universal value of the FCI.

We would like to propose that in the case of $64 \mathrm{a}$ and $64 \mathrm{~b}$, even though we are dealing with constituent negation, we are dealing with sentential quantification. If we take into account Kratzer (2005), it would seem plausible to defend that cualquier NP would trigger sentential quantification and not DP quantification. Thus, we would expect for it to involve a universal propositional operator, as well as the other subtrigged cases we have analysed. Then, we would expect that exh applied to the subtrigged cualquier NP, and a type shift e occurred to allow it to refer to the maximal collection of these days in $w_{0}$. Next, $\downarrow$ should be applied to avoid vacuous quantification with regards to the propositional universal quantification triggered by the universal indeterminate pronoun cualquier. We will assume that the universal indeterminate pronoun, which in this case denotes days, is introduced by an omitted preposition that allows it to introduce instances of times as in, $68 .{ }^{35}$ Thus, as predicted in the previous section, it will be perfectly grammatical.

\footnotetext{
${ }^{34}$ Note that a sentence involving the event of suicide and the existential algún would be fine: Si algún día me suicido lo haría escuchando Here comes the sun./ If some day I commit suicide, I would do it listening to Here comes the sun.

${ }^{35}$ We have not worked out the semantics needed to introduce the temporal modifier, which is why we propose the omitted preposition that would take the type e entity to introduce locations in times. Since typing the PP would force us to introduce intervals of times, as well as times, we will avoid its formalization.
} 
68. (a) Cualquier día de estos me suicido

'Any day of these I just might kill myself.'

(b) $[\forall]\left(\left(\right.\right.$ at $\downarrow\left(\mathrm{SHIFT}_{e}(\operatorname{exh}[\right.$ cualquier día, de estos] $))$ me suicido $)$

\begin{tabular}{|l|l|l|}
\hline En $d_{1}$ me suicido & En $d_{2}$ me sucido & $\ldots$ \\
\hline
\end{tabular}

We still need to explain the ungrammaticality of the negated cualquier $N P$, though the path is clearer. Since it is constituent negation, the negative operator remains within the temporal DP, and a possible alternative arises which is to follow Collins (2017). He defends that a DP of type e cannot be modified by negation, and that only generalized quantifiers which involve a $t$ in their type may be negated. Though the need for generalized quantifiers may be questioned (Kratzer, 2005, Matthewson and Davis, 2019, among others), what matters is that negation cannot interact with a type e phrase. Thus, we can defend that, since cualquier NP has been typed shifted to e, a representation such as 68b) should be generated. However, since negation cannot modify cualquier NP, the set of alternatives in 68c) cannot be generated, and the derivation fails: ${ }^{36}$

69. (a) *No cualquier día de estos me suicido 'Not Any day of these I just might kill myself.'

(b) $[\forall]$ (Me suicido at $\neg\left(\operatorname{SHIFT}_{e}(\operatorname{exh}[\right.$ cualquier día, de estos] $))$

(c) \begin{tabular}{|l|l|l|}
\hline Me sucido en no $d_{1}$ & Me sucido en no $d_{2}$ & $\ldots$ \\
\hline
\end{tabular}

We have provided, thus, an account which analyses this FCI as an indeterminate universal pronoun and that can explain why it cannot appear combined with negation when we are dealing with constituent negation of cualquier NP in a non-argumental position.

\section{Conclusions}

We hope to have shown that both in generic and episodic statements which involve negation we are dealing with a FCI associated to $\forall$ and not to $\exists$. We have provided further evidence to defend the universal character of cualquier by analyzing its interaction with negation. We have shown that it can appear in negative generic statements, defended that GEN operates over sets of alternatives, and the universal quantifier may apply to GEN. Thus, we do not get a contradiction. Then, we have defended that in negative episodic sentences there is covert subtrigging introduced by a covert modifier which involves the choice the agent makes. If we assume a universal approach to FCI cualquier we can account for its ability to appear negated, and the existential interpretation it gets when it is negated.

In addition to this, we have shown that a syntactic approach to the interaction of negation and cualquier NP can also be accounted for, if it were to be a universal quantifier. There is an interaction with FocusP when it appears fronted, that is, before the negative

\footnotetext{
${ }^{36}$ Ricardo Etxepare and Myriam Uribe-Etxebarria (2020) show that some varieties of Spanish allow for the negation of a type e. This could be a problem for Collins (2017), ourselves, and also Ricardo Etxepare and Myriam Uribe-Etxebarria (2020) who defend that only existential quantifiers, degree quantifiers, and comparative quantifiers may appear in constituent negation. Thus, it remains an open issue.
} 
operator. Nonetheless, it does not occupy the higher external position which is available for metalinguistic negation. We are dealing with ordinary sentence negation in Spanish.

We have also shown how our proposal could deal with non-argumental phrases that involve cualquier NP. We can explain their grammaticality when they appear non-negated, as well as their ungrammaticality when they are negated. Since we are dealing with constituent negation, and the phrase has been typed shifted into e, thanks to subtrigging, negation cannot occur.

Overall, we have shown through the interaction of negation and cualquier NP that FCI cualquier has a universal value, that an alternative semantics approach to it can account for its semantic behavior, that the syntax involving the phenomena is that of ordinary negation in Spanish, and that free choiceness can help us to account for the behaviour of cualquier in negative episodic statements.

\section{Acknowledgements}

This research was possible thanks to grant FCE_3 2018_1_148810 from ANII (Uruguay).

\section{References}

Aloni, Maria (2007a). "Free Choice and Exhaustification: An Account of Subtrigging Effects". In: Proceedings of Sinn Und Bedeutung. Vol. 11, pp. 16-30.

- (2007b). "Free Choice, Modals, and Imperatives". In: Natural Language Semantics 15.1, pp. 65-94. ISSN: 0925-854X, 1572-865X. DOI: 10 . 1007 / s11050-007$9010-2$.

- (2019). "Indefinites as Fossils: The Case of Wh-Based Free Choice." In:

Aloni, Maria and Robert Van Rooij (2007). "Free Choice Items and Alternatives". In: Proceedings of the KNAW Academy Colloquium: Cognitive Foundations of Interpretation. Edita KNAW Amsterdam, pp. 5-26.

Alonso-Ovalle, Luis and Paula Menéndez-Benito (2011). "Expressing indifference: Spanish un NP cualquiera". In: Semantics and Linguistic Theory. Vol. 21, pp. 333-352.

Arregui, Ana (2006). "Cualquier, Exception Phrases and Negation". In: AMSTERDAM STUDIES IN THE THEORY AND HISTORY OF LINGUISTIC SCIENCE SERIES 4 278, p. 1.

Beghelli, Filippo and Tim Stowell (1997). "Distributivity and Negation: The Syntax of Each and Every". In: Ways of Scope Taking. Ed. by Gennaro Chierchia et al. Vol. 65. Dordrecht: Springer Netherlands, pp. 71-107. DOI: 10 . 1007/978-94-0115814-5_3.

Bosque, Ignacio (1980). Sobre La Negación. Cátedra Madrid. ISBN: 84-376-0251-3.

Bustos, Eduardo (1986). Pragmática del español: negación, cuantificación y modo. spa. Aula abierta 3. Literaturverz. S. [267] - 272. Madrid: Univ. Nacional de Educacion a Distancia. ISBN: 978-84-362-1985-2.

Carlson, Greg N. (1989). "On the Semantic Composition of English Generic Sentences”. In: Properties, Types and Meaning. Ed. by Gennaro Chierchia et al. Vol. 39. Dordrecht: Springer Netherlands, pp. 167-192. DOI: 10 .1007/978-94-009-27230_5. 
Ana Clara Polakof

Chierchia, Gennaro (1998). "Reference to Kinds across Language". In: Natural language semantics 6.4, pp. 339-405.

- (2006). "Broaden Your Views: Implicatures of Domain Widening and the "Logicality" of Language”. en. In: Linguistic Inquiry 37.4, pp. 535-590. ISSN: 0024-3892, 15309150. DOI: 10.1162 /ling.2006.37.4.535.

- (2013). "Free Choice Nominals and Free Choice Disjunction: The Identity Thesis". en. In: Alternatives in Semantics. Ed. by Anamaria Falaus. London: Palgrave Macmillan UK, pp. 50-87. DOI: $10.1057 / 9781137317247$ 3.

Collins, Chris (2017). "The Distribution of Negated Quantifier Phrases in English". In: Ms., NYU.

Collins, Chris and Paul M. Postal (2014). Classical NEG Raising: An Essay on the Syntax of Negation. Vol. 67. MIT press. ISBN: 0-262-32385-0.

Corblin, Francis and Lucia Tovena (2003). "L'expression de La Négation Dans Les Langues Romanes". In: Les langues romanes: problèmes de la phrase simple, pp. 281-343.

Dayal, Veneeta (1998). "Any as Inherently Modal”. en. In: Linguistics and Philosophy 21.5, pp. 433-476. ISSN: 1573-0549. DOI: 10.1023 /A: 1005494000753.

- (2004). "The Universal Force of Free Choice <any>". en. In: Linguistic Variation Yearbook 4, pp. 5-40. ISSN: 1568-1483, 1569-9900. DOI: 10 . 1075 / Iivy . 4 . 02 day.

- (2009). "Variation in English Free Choice Items". In: Universals and variation: Proceedings of GLOW in Asia VII, pp. 237-256.

Espinal, Teresa (2000). "On the Semantic Status of N-Words in Catalan and Spanish". en. In: Lingua 110.8, pp. 557-580. ISSN: 00243841. DOI: 10 . 1016/ S0024$3841(00) 00002-4$.

Etxepare, R and M Uribe-Etxebarria (2011). "Foco y negación de constituyentes". spa. In: 60 problemas de gramática: dedicados a Ignacio Bosque. Ed. by María Victoria Escandell Vidal, Manuel Leonetti, and Cristina Sánchez López. Lingüística. Madrid: Ed. Akal. ISBN: 978-84-460-3427-8.

Etxepare, Ricardo and Myriam Uribe-Etxebarria (2008). "On Negation and Focus in Spanish and Basque". In: Anuario del Seminario de Filología Vasca” Julio de Urquijo”, pp. 287-309.

- (2018). "Context-Sensitive Aspects of Constituent Negation". In: Language, Syntax, and the Natural Sciences. Ed. by Roger Martin and Ángel J. Gallego. Cambridge: Cambridge University Press, pp. 77-98. ISBN: 978-1-107-15294-6. DOI: 10.1017 / 9781316591529.005.

- (2020). Two Strategies for Constituent Negation (with Data from Spanish Varieties). LSRL50!

Fox, Danny (2007). "Free Choice and the Theory of Scalar Implicatures". en. In: Presupposition and Implicature in Compositional Semantics. Ed. by Uli Sauerland and Penka Stateva. London: Palgrave Macmillan UK, pp. 71-120. ISBN: 978-1-349-28206-7. DOI: $10.1057 / 9780230210752 \_4$.

Gamut, L. T. F. (2002). Introducción a La Lógica. Trans. by Cecilia Durán. Eudeba Buenos Aires, Argentina. ISBN: 950-23-1224-4.

Giannakidou, Anastasia and Josep Quer (2013). "Exhaustive and Non-Exhaustive Variation with Free Choice and Referential Vagueness: Evidence from Greek, Catalan, and Spanish". In: Lingua 126, pp. 120-149. 
Grice, H. P. (1975). "Logic and Conversation". In: Speech Acts. Ed. by Peter Cole and Jerry L. Morgan. BRILL, pp. 41-58. ISBN: 978-90-04-36881-1. DOI: 10 . 1163 / 9789004368811_003.

Gutiérrez-Rexach, Javier (2014). Interfaces and Domains of Quantification. The Ohio State University Press. ISBN: 0-8142-1255-7.

Hintikka, Jaakko (1980). "On the Any-Thesis and the Methodology of Linguistics". en. In: Linguistics and Philosophy 4.1, pp. 101-122. ISSN: 0165-0157, 1573-0549. DOI: 10.1007 /BF00351815.

Horn, Laurence R. (1985). "Metalinguistic Negation and Pragmatic Ambiguity". In: Language 61.1, p. 121. ISSN: 00978507. DOI: $10.2307 / 413423$.

- (2000). "Pick a Theory, Not Just Any Theory". In: Negation and Polarity. Syntactic and Semantic Perspectives. Ed. by Laurence Horn and Yasuhiko Kato. Oxford: Oxford University Press, pp. 147-192. ISBN: 0-19-823873-8.

Horn, Laurence R. and Yasuhiko Katō, eds. (2000). Negation and Polarity: Syntactic and Semantic Perspectives. Oxford Linguistics. Series statement taken from jacket. Oxford ; New York: Oxford University Press.

Kadmon, Nirit and Fred Landman (1993). “Any”. en. In: Linguistics and Philosophy 16.4, pp. 353-422. ISSN: 0165-0157, 1573-0549. DOI: 10.1007 /BF 00985272.

Kaplan, David (1989). "Demonstratives: An Essay on the Semantics, Logic, Metaphysics and Epistemology of Demonstratives and Other Indexicals". In: Themes From Kaplan. Ed. by Joseph Almog, John Perry, and Howard Wettstein. Oxford University Press, pp. 481-563.

Kato, Yasuhiko (2000). "Interpretive Asymmetries of Negation". In: Negation and Polarity. Syntactic and Semantic Perspectives. Ed. by Laurence Horn and Yasuhiko Kato. Oxford: Oxford University Press, pp. 62-87. ISBN: 0-19-823873-8.

Kim, Jong-Bok and Ivan A. Sag (2002). "Negation without Head-Movement". In: Natural Language \& Linguistic Theory 20.2, pp. 339-412.

Kratzer, Angelika (2005). "Indefinites and the Operators They Depend on: From Japanese to Salish". In: Reference and Quantification: The Partee Effect. Ed. by Greg Carlson and Francis Pelletier. Vol. 173. CSLI Publications Stanford, CA, pp. 113-142.

Kratzer, Angelika and Junko Shimoyama (2002). "Indefinite Pronouns: The View from Japanese”. In: Paper Delivered at the Third Tokyo Conference on Psycholinguistics.

Krifka, Manfred (1991). "Some Remarks on Polarity Items". In: Semantic Universals and Universal Semantics. De Gruyter Mouton. Chap. Semantic Universals and Universal Semantics, pp. 150-189. ISBN: 978-3-11-087052-7. DOI: 10 . 1515/9783110870527009.

Krifka, Manfred et al. (1995). “Genericity: An Introduction”. In: The Generic Book. Ed. by Gregory N. Carlson and Francis Jeffry Pelletier. University of Chicago Press, pp. 1124. ISBN: 0-226-09292-5.

Laka, Miren Itziar (1990). "Negation in Syntax-on the Nature of Functional Categories and Projections". PhD thesis. Massachusetts Institute of Technology.

Lasnik, Howard (1972). “Analyses of Negation in English.” PhD thesis. Massachusetts Institute of Technology.

LeGrand, Jean Ehrenkranz (1975). "Or and Any: The Semantics and Syntax of Two Logical Operators (Ph. D. Dissertation)”. In: University of Chicago. 
Löbner, Sebastian (2000). "Polarity in Natural Language: Predication, Quantification and Negation in Particular and Characterizing Sentences". In: Linguistics and Philosophy 23.3, pp. 213-308. ISSN: 01650157. DOI: 10.1023/A:1005571202592.

Lorenzo González, Guillermo (1999). “Negación Sin NegP”. In: Verba 26, pp. 193-223.

Matthewson, Lisa and Henry Davis (2019). "Quantification". In: The Routledge Handbook of North American Languages. Ed. by Daniel Siddiqi et al. Routledge Handbooks in Linguistics. New York, NY: Routledge. ISBN: 978-1-138-62874-8.

Menéndez-Benito, Paula (2005). The Grammar of Choice. University of Massachusetts Amherst Amherst, MA. ISBN: 0-542-38344-6.

- (2010). "On Universal Free Choice Items". In: Natural Language Semantics 18.1, pp. 33-64.

Penka, Doris (2016). "Negation and Polarity". In: The Routledge Handbook of Semantics. Ed. by Nick Riemer. Routledge Handbooks in Linguistics. London ; New York: Routledge, pp. 303-319. ISBN: 978-0-415-66173-7.

RAE (2009). Nueva Gramática de La Lengua Española. Espasa Libros.

Rivero, Marıa Luisaz (2011). “Cualquiera Posnominal: Un Desconocido Cualquiera”. In: Cuadernos de la Asociación de Lingüıstica y Filologıa de la América Latina 3, pp. 6080.

San Segundo Cachero, Rosabel (2016). "Negación Metalingüística y Estructura Informativa: Caracterización Sintáctico-Pragmática de" Non"”. In: Lletres asturianes, 114.

Sánchez López, Cristina (1999a). "La Negación”. In: Gramática Descriptiva de La Lengua Española. Ed. by Ignacio Bosque and Violeta Demonte. Vol. 1. Espasa Calpe Mexicana, SA, pp. 2561-2634. ISBN: 84-239-7918-0.

- (1999b). "Los Cuantificadores: Clases de Cuantificadores y Estructuras Cuantificativas". In: Gramática Descriptiva de La Lengua Española. Ed. by Ignacio Bosque and Violeta Demonte. Vol. 1. Espasa Calpe Mexicana, SA, pp. 1025-1128. ISBN: 84-2397918-0.

van Rooij, Robert (2008). “Towards a Uniform Analysis of Any”. en. In: Natural Language Semantics 16.4, pp. 297-315. ISSN: 0925-854X, 1572-865X. DOI: 10.1007 / s11050-008-9035-1.

Vendler, Zeno (1974). "Each and Every, Any and All." In: Linguistics in Philosophy. Cornell University Press. ISBN: 978-0-8014-0436-8.

Zanuttini, Raffaella (1997). Negation and Clausal Structure: A Comparative Study of Romance Languages. Oxford Studies in Comparative Syntax. New York: Oxford University Press.

Zeevat, HW (1994). "Applying an Exhaustivity Operator in Update Semantics, in: Ellipsis, Tense and Questions (Hans Kamp". In:

Zeijlstra, Hedde (2004). Sentential Negation and Negative Concord. eng. LOT 101. @ Amsterdam, Univ., Diss., 2004. Utrecht: LOT. ISBN: 978-90-76864-68-6. 